\title{
Gender as a Barrier for Women With Children in Academe
}

\section{CARMEN ARMENTI}

Portland State University

\section{ABSTRACT}

This research involved in-depth interviews with nineteen women professors, drawn from across various faculties and ranks at one Canadian university, and was intended to explore the interconnections between the women's personal and professional lives. The women in this study chose to combine having children with an academic career. Most of them depicted their career trajectory as a lifelong challenge, one that was both fulfilling and prestigious. In contrast, the women reported a number of obstacles in their career paths that served to prevent them from gaining full membership in academic life. This study probes the nature of such obstacles that are grouped into two categories: the child-related time crunch and the career-related time crunch. As a result of these obstacles, the women encountered childbearing/childrearing problems, research dilemmas, a willingness to leave the academy, and denial of tenure and promotion. Findings call for a restructuring of academic careers in order to effectively accommodate women with children in the profession. 


\section{RÉSUMÉ}

Cette recherche se base sur des entrevues en profondeur impliquant dix-neuf professeurs féminins de divers rangs et provenant de diverses facultés d'une université canadienne. Le but de la recherche était d'explorer les liens entre les vies privée et professionnelle de ces femmes qui ont choisi de fonder une famille tout en poursuivant leur carrière universitaire. Plusieurs de ces femmes ont décrit la trajectoire de leur carrière comme étant un long défi qu'elles considèrent prestigieux et offrant une occasion d'épanouissement personnel. Cependant, elles ont aussi decrit un certain nombre d'obstacles rencontrés dans leur cheminement et elles croient que ceux-ci les ont empéchées d'intégrer complètement une vie universitaire. Cette recherche tente d'élucider la nature de ces obstacles qui sont regroupés en deux categories: le temps dédié à élever les enfants et le temps dédié à la carrière professionnelle. Pour ces femmes, ces obstacles ont les conséquences suivantes: des difficultés concernant la maternité et celles à élever les enfants, des dilemmes en recherche et des difficultés que certaines doivent affronter lorsqu'elles quittent volontairement leur poste en se voyant ainsi refuser de l'ancienneté d'emploi ainsi que des promotions liées au poste. Les données de cette recherche démontrent qu'il est grand temps que ces inégalités soient reconnues afin d'établir des moyens plus efficaces pour admettre adéquatement des femmes avec des enfants à charge dans la profession universitaire.

Women academics in Canadian universities constitute a small percentage of faculty members and their numbers drop significantly as their rank increases (Drakich \& Stewart, 1998). Statistical figures that reveal a growth in the number of women in the professoriate are deceiving, for most of these women are found in the junior ranks (Mather, 1998). "Few women become full professors" (Donaldson \& Emes, 2000, p. 52). In 1999-2000, women faculty in Canadian 
universities constituted only $25.9 \%$ of full-time faculty: of those $14.4 \%$ were full professors, $30.5 \%$ were associate professors, and $41.8 \%$ were assistant professors (Stanley, Robbins \& Morgan, 2002). In 2001-2002, the proportion of full-time women faculty had increased to $29.3 \%$, although many of them were in non-tenured positions $(42.4 \%)$, a similar proportion were on the tenure-track $(39.1 \%)$, and a smaller percentage were tenured (21.5\%) (Stanley, Robbins \& Morgan, 2003). According to Krause (1999), adjunct and part-time faculty are the underclass in the academy and they tend to be mostly women. Numerical studies, however, tell only part of the story for qualitative studies report that women academics feel excluded, isolated, and marginalized in this profession (Aisenberg \& Harrington, 1988; Caplan, 1993; Chilly Collective, 1995). As well, the academic environment has been referred to as a maleidentified culture (Tierney \& Bensimon, 1996). The profession continues to revolve around the male life trajectory; there is little acknowledgment that the woman's life cycle is different, with a few exceptions in the form of policies designed to permit women to have both children and a career.

This study is an examination of the obstacles to full employment encountered by women professors when they choose to have children; in that, the academic system functions in various unfavourable ways toward women even after they have gained entry to tenure level positions. There are a total of 19 participants, ranging in age from 30 to 60 , and occupying the tenure-track ranks of assistant, associate, and full professor. Many of these women have children or are planning to have children. Their words derive meaning from the personal demands and individual sacrifices encountered by overlapping the private and public spheres. While, in general, they are content with their career choices, they also express dissatisfaction with various aspects of academic life.

Throughout this work, the women's stories create a tapestry of realities concerning their lives in the university that make them appear to be second class citizens in academia. Their words echo 
the voices of feminist scholars, such as Simone DeBeauvoir (1952), who called women the "second sex"; Nadya Aisenberg and Mona Harrington (1988), who labeled women academics as "outsiders" in their chosen profession; Sandra Acker (1994), who described them as the "other academics"; Jennifer Mather (1998), who portrayed them as "second class citizens"; and Jane Roland Martin (2000), who called them "immigrants." Not only do the women professors in this study continue to match these descriptions, but they also provide clear and precise explanations for their subordinate status. Indeed, women's identities in this male profession are murky. They are viewed not as women, nor as men, nor as gender-neutral beings. Instead they are expected to play the role of women when the situation commands and that of men in other circumstances. For example, they must adapt to the male life trajectory for the purpose of tenure and promotion, but they are expected to assume the traditionally feminine role of caregiver and nurturer towards the students. Accordingly, the obstacles that these women encounter in their career serve to delineate their outsider status.

The initial part of this article reviews the research literature focusing on how the career paths of women academics differ from their male colleagues. From a cultural feminist perspective, woman's life trajectory has not been sufficiently researched within this literature, and this omission makes invisible some of the obstacles along women's career paths. After a description of the study and the participants, excerpts from the interviews are used to identify the obstacles faced by women with children in academe. Drawing on the women's stories and feminist literature, a gendered analysis of academic careers is provided by means of a depiction of the ways in which the academy fails to effectively accommodate women, for to do so our current perception surrounding issues of career and family planning, as well as gender differences in the workplace, must be reconstructed-essentially through changes made in institutional structures. 


\section{CULTURAL' FEMINISM AND ACADEMIC CAREER PATHS}

Cultural feminism recognizes that women and men are different and that the dominant public and professional ways of talking, behaving, and valuing have been male-oriented (Bank and Hall, 1997), making it necessary to question gendered assumptions, support programs oriented toward women, and value women's ways of knowing, acting, and talking. Cultural feminists think that educational institutions should function on the basis of collaboration, rather than competition, generating a need to re-examine structures, policies, and leaders so that the private sphere is no longer excluded and devalued in the domain of the public sphere. Women's voices, as well as their personal and professional experiences and perspectives, should be integrated in the formulation of theory, policy, and practice. In turn, these new insights would support an ethic of care as the underling building block for alternative models of leadership that incorporate connections among all those involved in educational institutions (Gilligan, 1982; Noddings, 1992). Based on this view, the interconnections among childbearing, childrearing, and career issues are important components to consider when examining women's career progression-these are the topics of the current study.

Mather (1998) points out that the reason the academic system functions unfavorably toward women who have gained entry is because of "two social pressures": (1) the assumption that women should sacrifice a part of their lives to provide family care because this realm is their responsibility; and (2) the pressure for women to assume the greater responsibility of teaching and caring for students because of the stereotype that their gender is more suited to this type of labour than to research work. The women in this study would agree that these two pressures form important obstacles in their career path. If we picture the academic career path for men as more or less a straight (or perhaps curving) road and that for women it is more a 
road with many barriers, then the first social pressure can be termed the child-related time crunch. Because the academic profession continues to revolve around the male life trajectory, women who want to have children must struggle with decisions early on in their careers about the planning and timing of their pregnancies, which later becomes a struggle to combine childrearing with work. Few studies focus on the impact of childrearing on the careers of women professors. Orel and Whitmore (1998) note that untenured women seem particularly vulnerable in their ability to seek and receive parental leave due to fear of reprisal. Finkel and Olswang (1996) find that "women perceive the time required to rear children as one of the main impediments to tenure; this direct demand on academic women's time may contribute to the persistent inequality for many women in academia" (p. 135). Other studies show that women are more likely than men to leave the academy to care for children (Chused, 1985; Hensel, 1991), or to interrupt their career for child care reasons, which diminishes their probability of achieving tenure (McElrath, 1992). Caplan (1993) points out that while some women abandon academia to assume childrearing responsibilities: "nearly half the women who stay are either single or childless" (p. 185).

The second social pressure, that of assuming the responsibility of teaching and caring for students, is another obstacle along the road to equality for women academics; one which can be identified as the career-related time crunch. The emphasis on overworked women academics has become more common in current literature. Acker and Feuerverger (1997) find that women academics do a disproportionate share of the service related work in the department, yet the participants in their study believe that they are not adequately rewarded for their efforts. Some organizational theorists have likened the gendered division of labour in the home to that of the academic workplace (Calas \& Smircich, 1993; Johnsrud \& Heck, 1994) and other organizations, wherein "men's work" is thought to be more difficult and complex than "woman's 
work" (Kanter, 1977). In universities, women do more of the work associated with caring for others, whereas men do more of the intellectually oriented research and publication work. "Hence, the gender-role segregation results in a gender-role hierarchy in which the jobs identified as (culturally) feminine and allocated to (biological) women are undervalued and underpaid" (Park, 1996, p. 47). This gender role segregation and hierarchy has a negative impact on women's career progression. The Canadian Association of University Women conducted a study in 1991 revealing that across Canada, within the previous five years, only 25 percent of faculty receiving tenure were women (as cited in Saunders, Therrien, \& Williams, 1998). Those universities that had identified barriers to women's tenure reported biased hiring processes, male-domination in many departments, problems in balancing work and family, and excessive academic and administrative responsibilities.

Donaldson and Emes (2000) argue that a critical mass (35\%) of women academics is required to promote change in Canadian academia. This critical mass has not been reached in research as measured by "scholarship about higher education," in teaching as calculated by "participation rates within academic ranks," and in service as measured by "frequency of administrative appointment" (p. 33). They conclude that the results are a reflection of the relatively recent increase of women entering academic careers and family commitments or the woman's life cycle. Consequently, women's "progress through the ranks is slower and may arrest before they reach the highest levels" (p. 51). They further note that even though this career pattern prevails, rarely is the impact of a woman's life path on her academic career formally researched or taught. The above studies stop short of examining the voices of a group of women faculty expressing their own experiences concerning work and family. The stories of the women in this study seek to redress some of the missing information in scholarly literature. 


\section{METHOD}

Through in-depth qualitative interviews in June 1996, the 19 women professors in this study spoke about their personal and professional lives. The women were in the ranks of assistant, associate, and full professors within a variety of faculties at one Canadian university, namely the humanities, social sciences, sciences, and professional schools (Table 1). They ranged in ages from 30 to 60 making it possible to compare and contrast generational experiences and perceptions among women in the various ranks. Most of the participants were white middle-class women, with the exception of one who had a minority status, but grew-up in a middle-class family. Three respondents were from a working-class background. Very few minority and working class women academics were employed at this university at the time the data were collected.

As a result of the letter of invitation that outlined the study's purpose to examine the interconnection between academic careers and family life, most of the women in this study either had children or were planning to have children. While two of the assistant professors had adult children, many had young children or spoke of the possibility of having pre-tenure or post-tenure children. Two associate and two full professors also had young children at home and the other women in these ranks reported that their children were either teenagers or adults. Only one full professor in this study indicated that she had no children; however, she noted that this was not an actual choice that she made, but simply a result of the way her life proceeded.

The semi-structured interviews allowed the women to provide lengthy responses, change the order of the subject matter, and introduce new topics (see also Aisenberg \& Harrington, 1988). The duration of the tape-recorded interviews ranged from ninety to one hundred and twenty minutes, largely depending on the amount of time which the participant had available. These interviews were 
later transcribed and interpreted by establishing themes and using a coding system involving codes (which depict events, personal views, and behaviors) and subcodes (which diminish codes into smaller categories) (see Bogdan \& Biklen, 1992).

Table 1

\section{Profile of the Participants}

\begin{tabular}{|c|c|c|c|}
\hline & Rank & Gaculty & Age Range \\
\hline Nancy & Assistant & Arts & $30 \mathrm{~s}$ \\
\hline Carol & Assistant & Arts & $30 \mathrm{~s}$ \\
\hline Patricia & Assistant & Social Sciences & $30 \mathrm{~s}$ \\
\hline Vanessa & Assistant & Social Sciences & $40 \mathrm{~s}$ \\
\hline Gynthia & Assistant & Sciences & $30 \mathrm{~s}$ \\
\hline Rachel & Assistant & Sciences & $30 \mathrm{~s}$ \\
\hline Martha & Assistant & Professional & $30 \mathrm{~s}$ \\
\hline Audrey & Assistant & Professional & $50 \mathrm{~s}$ \\
\hline Ellen & Associate & Arts & $50 \mathrm{~s}$ \\
\hline Natalie & Associate & Arts & $40 \mathrm{~s}$ \\
\hline Qhivian & Associate & Social Sciences & $40 \mathrm{~s}$ \\
\hline Madeleine & Associate & Sciences & $50 \mathrm{~s}$ \\
\hline Janice & Associate & Sciences & $40 \mathrm{~s}$ \\
\hline Bridget & Associate & Professional & $30 \mathrm{~s}$ \\
\hline Pamela & Associate & Professional & $60 \mathrm{~s}$ \\
\hline Megan & Full & Arts & $40 \mathrm{~s}$ \\
\hline Paula & Full & Social Sciences & $40 \mathrm{~s}$ \\
\hline Lauren & Full & Sciences & $40 \mathrm{~s}$ \\
\hline lirene & Full & Professional & $50 \mathrm{~s}$ \\
\hline
\end{tabular}

All names assigned to the participants are pseudonyms.

In the interpretation process, recurring patterns in the women's personal experiences served to indicate particular themes and codes. 
The study is credible and dependable for it addresses researcher bias by using such strategies as thick description of the women's stories which is a presentation of their own words to explain the situation at hand (Lincoln \& Denzin, 1994); negative case analysis whereby alternative interpretations that do not fit the data are eliminated; and methods triangulation which consisted of examining the interview transcripts in conjunction with a demographic questionnaire completed by each participant at the end of the interview and documents collected at the university in question (Creswell, 1998).

Documentary data that were collected revealed that this university had a maternity leave plan, as well as a policy that permitted women who bear children during their tenure track years to temporarily stop the "tenure clock." The university daycare center provided preferential access to students with children. Other established equity mandates included employment equity and sexual harassment policies and procedures. A Women's Study department existed on campus and some of the women in this study had been members of a university Women's Caucus since the early 1980s. Despite these equity initiates and practices, the women reported that they encountered, on a daily basis, a set of obstacles that made them feel like outsiders in the halls of academe.

\section{OBSTACLES TO GENDER EQUITY IN ACADEMIC LIFE}

The women in this study were a privileged group, by and large, who found their way into academic life. They were happy in many ways as depicted by Natalie, Vanessa, and Paula consecutively. "I have a job that's interesting, challenging . . . provides an unusual amount of autonomy and flexibility." "I love what I do . . there's no better job in the world." "I find it intellectually fulfilling." Most of the women indicated that they valued at least three aspects of their occupation: (1) the control that they had over their working hours; 
(2) the lack of supervision; and (3) the right to determine their own course of research. As Audrey put it, "I enjoy the independence of my job." Similarly, Martha noted, "I get to do research on issues that interest me." Notwithstanding the positive aspects of their careers, the women find obstacles in their path: the child-related time crunch and the career-related time crunch. These obstacles create a gender barrier to equity for women with children in the academy, in the sense that the system is less favourable to their needs.

\section{The Child-Related Time Crunch}

Three issues form the basis of the child-related time crunch: childbearing, childrearing, and research pressures. Each of these issues is discussed in detail by including excerpts from the interviews. Childbearing provided a prime example of a major restriction that academic careers placed on the women's personal lives. In terms of the planning and timing of maternity, the women attempted to fit this life experience into their career schedules. The senior women told stories about hiding their pregnancies or having their children in the month of May so as not to disrupt the teaching sessions in their departments, an act that they believed would jeopardize their careers. Irene, a full professor, used a clothing strategy to conceal her pregnancy during the winter term.

The baby was due in July, so . . . there were whole numbers in my Department that didn't seem to know, even by April, that I was pregnant because of the strategy that I had at the beginning, of wearing tight things one day and then voluminous things the next day. . . . By the time I was wearing lots of voluminous things, nobody noticed that they were any different from what they had seen.

Janice, an associate professor, explained why her pre-tenure baby was a May baby: “. . . you don't want your colleagues to resent you when you come up for tenure ... and so I had this May baby and came back to work in August." For her post-tenure baby 
she asserted: "I intentionally didn't have a May baby ... I had a December baby . . . that really threw the Chair for a loop." Janice recalled attending a women's caucus meeting in the mid 1980s where she discovered that many of the younger women professors were attempting to give birth in the month of May so as not to interrupt the teaching schedules in their respective departments. At this university, the practice of childbearing in the month of May by women professors was so widespread that it became known as the "May Baby Phenomenon" at women's caucus meetings.

The women junior faculty members still experienced personal anxiety surrounding the potential risk to their careers by having children before obtaining tenure; they believed that the solution was to plan to have children after getting tenure. Rachel, an assistant professor stated:

Tenure. Tenure, tenure first. I think, like ultimately it's very difficult to do it [have a baby] unless you know you are well established and when you're trying to establish yourself and establish family at the same time, I'm not convinced it's something I could have done.

Bridget provided additional details, "If you look through the university you will find very few women who have children. There are women, but they are single or they wait until they're tenured to have their children." Martha reported, "I've given up a lot to get here ... I hope the decision that I've made to have my own little family won't hurt me career-wise."

For both generations of women, the very act of having pretenure children was seen as an obstacle to their career progression. Attempting to control the timing of childbirth seems problematic in that some women have a difficult time getting pregnant, others have complicated pregnancies, and still others do not have healthy newborns. Natalie had two pre-tenure children and she felt fortunate that she was able to deliver them in the months of May and June, however she maintained that the spring academic baby boom was an unrealistic model for young women academics.

The Canadian Journal of Higher Education

Volume XXXIV, No. 1, 2004 
Childrearing was seen as problematic mostly in the sense that both older (Audrey) and younger (Carol) women told similar stories about not having access to the university childcare facility.

I was going to put him in the daycare center up here, but faculty were last on the list. . . . Full-time students, part-time students, something with the graduate and undergraduate students, there's a priority, and then staff and then faculty. . . By the time they said we have a spot for him, he'd been quite comfortable with somebody ... I hired. (Audrey)

The faculty benefits are ... mostly geared towards older men. For example, they [benefits] pay for tuition, but not childcare. The University daycare gives priority to undergraduates; faculty can be on the waiting list for years. (Carol)

Bridget described the problems inherent in another university policy established to permit women to have both children and a career. "Because of a maternity leave, I was eligible for an additional year's extension, which I did not want to take. I was exhausted ... I didn't have the journal articles in the process that, if I waited a year, would make or break my CV." Moreover, budget restraints limited the salary ranges for junior assistant professors, which in turn impacted on their financial ability to support children. Carol noted, "The financial constraints of the University make it difficult for me to be the sole earner ... I don't think it was quite so tricky back when my male colleagues were the sole earners in their families, but right now it's very tricky."

Research pressures occurred due to the fact that women professors with young children usually have a smaller proportion of time to devote to research, the production of which is necessary for achieving tenure. In this sense, the profession's long-standing unwritten policy of determining a person's career security on the basis of quantity of publications is geared toward the male life trajectory. Janice stated, 'I'm a mother with a family, I mean I didn't 
have the children to ignore them, and I feel that I've had less time to devote to my research."

The women with children tackled two very demanding jobs and they highlighted the difficulties inherent in performing double duty. Although the women in this study identified women with children as performing double duty, in actual fact these women perform triple duty when taking into consideration household labour. Natalie noted that a negative aspect of her career is "the fatigue, if you're trying to do two jobs basically. ... I think for most people with small children, it's finding enough connected time, not just scraps and patches of time-to do serious research is a big problem." Bridget described her mornings as follows:

My husband had already left for work by about six in the morning, so I had to get the two kids up, fed breakfast, their lunches made, myself showered and fed. I had to take my eighteen month old to a neighbor, I had to drive my [three year old] son to a daycare center, and then arrive at work by eight o'clock so I could teach. I felt like I had done my whole day's work before eight o'clock in the morning.

\section{The Career-Related Time Crunch}

Various issues served to document the career-related time crunch: research pressures, willingness to abandon the academy, and denial of tenure and promotion. The research pressures discussed in this section pertain to the demands of the university as an institution. One facet of time was that the lack of it interfered with the women's abilities to conduct research. The financial constraints in the universities required the faculty members to accept extra duties, which served to limit their time for research. According to Audrey, "I find, I don't have as much time to devote to it [research], as I need. . . . I think because they've cut faculty and staff . . . we've got fewer and fewer faculty ... [doing] the same job." In turn, low research output led to lack of funding which had an impact on job 
security by undermining their tenure and promotion endeavours. The assistant professors worried about obtaining tenure. Vanessa pointed out that ". . . the worry about tenure, it never goes away." Patricia noted, ". . . it's the researching that really causes me a lot of stress." Similarly, Martha was concerned about the impact of insufficient time for research on her tenure possibilities. There was an interesting contradiction in her words for she believed that the tenure stress that she was experiencing was a personal flaw, rather than a systemic problem.

There's so many pulls on my time right now, I have to be very structured and I find that difficult; like what should I do first, where should I focus my time with the tasks that I have. . . It's self-imposed stress because this tenure clock is ticking, as they say.

The associate professors worried about the limited possibilities for career advancement. Janice was concerned about the impact on promotion of the lack of time for research. "The hours that you have to put in if you want to really excel are excessive." Even the full professors were concerned about the impact of lack of time on their ability to obtain funding and, in turn, maintain job security. According to Lauren, " there's a huge stress component to it . . especially right now with University cutbacks. . . I mean even with tenure your job's in jeopardy."

Willingness to abandon the academy arose because the women expressed guilty feelings related to the time that they devoted to their children. They felt that they should spend most of their time working and if they were not working they were thinking about work because as Vivian put it, "It haunts you, it consumes you." Similarly Megan noted, "I suppose the down side is that with this kind of job, it's never done, so you don't feel at home. . . Y You can't leave your job at five o'clock and go on with your life." Audrey explained this guilt phenomenon as follows: "Sometimes it gets difficult to stretch yourself thin enough. . . I do get variety in my 
work but the hours can be very, very long. I get tired of feeling guilty because I'm not working."

The women with young children expressed an internal conflict, which on the one hand pulled them to spend time with their children, and on the other hand pulled them in the opposite direction, back to work. Patricia described the conflict between work and family as one that is difficult to resolve, virtually requiring a woman to be in two places at one time. She expressed a great deal of anxiety over working and leaving her children in the hands of a caregiver. "I'm getting up every morning and I'm going into work, when all I want to do is stay at home and take care of her, because she's so miserable." This conflict between her career and children may cause her to leave the academy in search of a career that is more compatible with raising children. "I think maybe it would be great to work at a women's shelter or something that wouldn't be so much pressure." In contrast, she explained, "I have two girls, and ... I want them to grow up, and ... see what women can do. And sometimes when I'm really down, I think the only reason I'm doing this is so that they have this great role model."

For some women the denial of tenure and/or promotion gave them the perception that their gender interfered with their academic success. Vivian had a negative tenure experience. She was initially denied tenure, but she appealed that decision and won. As a result, in describing herself as an academic she had accepted the notion that she was mediocre. She was convinced that she would never achieve the level of full professor because she was unwilling to put herself, once again, through the ordeal of a promotion process and its potential negative effect on her self-esteem. She noted that many women seemed to end their career at the associate level. Although she wondered why that was the case, she speculated that other women may tell stories that resembled her own experience. "If you look at my life as an academic, I'm okay, I'm not great, I will probably never be a full professor. . . I'd never go through 
that process again." Bridget, who also had a discouraging tenure experience, believed that the Chair of her department, who was a man, "tended to foster the careers of other men who were in his networking circle." She elaborated:

There were four of us who went up for tenure. I do know that the two men who went up for tenure had no trouble and the two women did .... The woman who was an excellent teacher and had a relatively weak research portfolio failed her tenure and had to seek new employment. I had a very strong research profile and a relatively weak teaching portfolio .... I had to go through an appeals process to get tenure. I found it quite demoralizing. By the end of it all, I had a full case of clinical depression.

As for the associate professors, Janice and Madeleine believed that they were unlikely to reach the level of full professor due to a lower number of publications compared to male colleagues. Janice was the first woman in her department to have a baby prior to obtaining tenure. Although she was granted tenure after six years of employment, it took her four more years to be promoted to associate professor. "I was annoyed that they didn't give me the promotion at the same time...it was like getting a pat on the back and a kick in the stomach." At the time of the interview, she had been an associate professor for nine years, making it a total of nineteen years of service to the university, but she had no prospects of ever attaining the level of full professor. In her words, what was required to get a promotion was being "a world class scholar with a very long publication record." Madeleine not only did most of the student counseling in her department, she also taught more courses than her male colleagues. As a result, she had less time to devote to research and thereby lost most of her research grants. She blamed herself for not realizing that the extra work meant less research. "I was asked to do them; I was eager to prove myself; I assumed that the research would come along okay. I didn't assume correctly ... nobody told me . . . I should have figured it out myself." 


\section{DISCUSSION}

Cultural feminism posits that within public life the preferences of women are subordinated to the inclinations of men toward traditional ways of building careers, as well as organizational cultures. Stemming from the work of Noddings (1992) who believes that caring should be an important aspect of teaching and Gilligan (1982) who attributes an ethic of care to women, cultural feminism celebrates the differences that women bring to the professions, such as attributes of nurturance, caring, and kindness. Cultural feminists also believe that women have particular "ways of knowing" and organizing the world (Belenky et al. 1986). The stories of the women in this study support Bensimon and Marshall's (1997) assertion that to attain equality the differences between the sexes must be recognized, so that women's differences are valued.

In academia, productivity is measured on the basis of research publications. According to Caplan (1993): "publications count far more for tenure and promotion than do teaching and service to the institution, the profession, and the community" (p. 65). Moreover, the "quantity of publications is far more important than various measures of quality of publications in predicting rank advancement" (Long, Allison, \& McGinnis, 1993, p. 703). The ideal academic career that once demanded high productivity from the start for both women and men now extends that demand to graduate (and even undergraduate) students aiming at an academic career (Cassuto, 1998). Attitudes towards gender roles, however, have not progressed as rapidly as productivity goals, for it is still true that unlike most female academics, male academics usually have the luxury of putting their careers ahead of household responsibilities and child care, since quite often their female partner will assume responsibility for the domestic realm (Smart \& Smart, 1990; Duxbury, Heslop, $\&$ Marshall, 1993). This increased demand for productivity by 
graduate students neglects to take into account the female life trajectory and serves to compound the problem for women who want to experience combining career and children in their lives. Publishing necessarily requires more time in graduate school and financial hardships can make it difficult for women graduate students to support children; instead, those who want children may wait until they obtain an academic position. Even then, for productivity and tenure reasons, junior women academics may postpone the timing of childbirth further into the future.

The women's stories in this study demonstrate the necessity for further change before women gain equality in academe. Young women faculty encounter a major hurdle when trying to combine childbearing with the pursuit of tenure; that is, many women are in their thirties when they begin an academic career that coincides with their childbearing years (Committee on the Status of Women, 1988). Additionally, women experience a higher risk of infertility above the age of thirty-five. Senrono Laboratories (1997) has compiled a booklet of information about the increased risk of infertility above the age of 35 and the treatment options available to women. For the sake of tenure, however, the young women in this study preferred to take the risk of delaying maternity. Indeed, both the junior and senior women believed that the very act of having children before obtaining tenure became an obstacle to their career progression. Beyond the women's dilemmas on deciding the timing of childbirth was finding sufficient time to prepare for tenure and promotion while raising a child. The child-related time crunch revealed in this research serves as a clear indication that academic careers are still based on a male life trajectory. Over three decades ago Hochschild (1971) assumed that academic careers followed the clockwork of the male life cycle. This research not only validates that assertion, but also shows that in the realm of work and family, academic careers have not progressed to accommodate the needs of a growing number of women in the profession. 
In 1970, the report of the Royal Commission on the Status of Women identified childcare as a major concern for women working outside the home. Over a decade later, Judge Abella (1984) noted that childcare in the workplace was a necessity. In 1988, Dagg and Thompson argued for university services to be extended to include childcare responsibilities. Yet another decade later, Hornesty (1998) noted that the childcare crisis persisted within universities. Some Canadian universities still did not have on-campus childcare facilities; and of those that did, most did not provide infant care, after-school care, nor flexible hours to meet the needs of academic parents. Hence, for over thirty years women have been struggling for recognition of family responsibilities within the workplace. Beyond the need for adequate childcare within the workplace, Saunders, Therrien, and Williams (1998) recommended flexible and respected job alternatives for faculty, such as job-sharing and parttime faculty positions. In light of the fact that biological and tenure clocks tick away simultaneously, Coiner (1998) argued that infant care requires early sabbaticals for some faculty members. Are the above recommendations necessary or even sufficient to meet the needs of women academics with children?

An academic career requires continuous day-to-day work, and there is no clear delineation between work and personal life. The women indicated that the flexibility of their hours permitted them to combine both children and a career. This was not easy, as in a sense some of them (especially the women with young children) were maneuvering three full-time jobs (see also Grant, Kennelly, \& Ward, 2000), but the control that they had over their hours made it somewhat feasible. Nevertheless, the women felt guilty when they were not working, both because there was so much work left undone, and because they were preoccupied with their work while spending time with their children. Many of the women pointed out that the portion of time that they could devote to research was insufficient and a major source of stress. Clearly, from a cultural 
feminist perspective that places great value on the interconnection between the private and public spheres, women's personal lives remain invisible in the academic milieu. Even in the context of what women have achieved in terms of contract provisions for maternity leaves and policies to stop-the-tenure clock, the women in this study felt disempowered. Keahey and Schnitzer (2003), the editors of a powerful collection of stories written by women in the Canadian academic system, point out that the preponderance of issues related to motherhood in this collection exposes the magnitude of problems faced by women with children in academia. The standards expected of female faculty to achieve the same rank as men, serve to maintain "unapologetically ... [the] able-bodied, white, heterosexual, middle class" male model of an academic (Heald, 2002). In recent years, the common ideology within universities is one of increasing the workload and capacity of people (Reimer, Cassin, Eyre, \& Gordon, 2002), which further serves to disadvantage women academics with children. In short, despite the inter-generational change in contract language, the younger and older women felt equally ineffective for they spoke of budget restraints that affected their personal and professional lives, lack of time for research which impeded career progression, and reluctance of universities to be responsive to childbearing and childrearing needs of parents.

To ensure equity in academia for women with children, cultural feminists would argue for a restructuring of academic careers to accommodate the female life path and to reward relationships of caring, so that concern for others is of top priority in this profession. This work began with the premise that women faculty can still be described as outsiders, the other academics, second class citizens, and even immigrants. The introduction of provisions such as half-time or part-time tenure track positions, university daycare facilities that cater to the working hours of faculty members, and early sabbaticals for infant care would constitute progress toward the inclusion of women as full members in the academic profession. 


\section{CONCLUSION}

The women in this study truly enjoyed and appreciated their careers. Most of them appeared to view the academic career path as a lifelong challenge. They found this position to be fulfilling and prestigious, and some even described it as the best job in the world. Despite the women's depictions of positive career-related aspects, entry into the academic profession for women did not imply that their future paths would be smooth; rather, they encountered genderrelated obstacles that prevented them from gaining equality in the academy. Many of these obstacles were derived from the prevailing social ideology that a woman's primary responsibility is to her children and family (Mather, 1998). Other obstacles were based on the gender stereotype that research is men's work and teaching and service is women's work (Park, 1996). Partly as a result of these gendered assumptions, the women faced childbearing/childrearing problems, research dilemmas, a willingness to leave the academy, and denial of tenure or promotion in the academic environment - all of which served to act as detriments to their career progression.

In this profession, the women received overt and subtle messages indicating that they were different and somewhat inferior to their male colleagues. They were given this impression in overt ways because few women were promoted to the level of full professor (as stated by the women in this study) and others underwent devastating appeal procedures to receive their tenure status (as did both Vivian and Bridget). In more subtle ways, their personal lives were silenced, yet they were expected to use their nurturing instinct without recognition or reward. One interpretation of these findings is that women are tolerated rather than accepted in the academy.

In contrast, the women used a largely individualistic framework to describe their situations. Even when there was some acknowledgment of a systemic problem such as gender bias, it often reverted to a comment about themselves; for example, "It's self imposed stress," 
"It's made me more anxious," "I'm okay, I'm not great," and so forth. The women made some references to social constraints, but nonetheless, depicted a strong theme of blaming themselves or at least seeing themselves carrying the responsibility for their own fate. It is important that obstacles to full employment for women academics with children become visible so that women can see other women living similar experiences and likewise experiencing social constraints.

\section{References}

Abella, R.S. (1984). Equality in employment: A Royal Commission report. Ottawa: Ministry of Supplies and Services.

Acker, S. (1994). Gendered education: Sociological reflections on women, teaching and feminism. Toronto, ON: OISE Press.

Acker, S., \& Feuerverger, G. (1997). Enough is never enough: Women's work in academe. In C. Marshall (Ed.), Feminist critical policy analysis: A perspective from post-secondary education. Washington, D.C.: Falmer Press.

Aisenberg, N., \& Harrington, M. (1988). Women of academe: Outsiders in the sacred grove. Amherst: University of Massachusetts Press.

Bank, B.J., \& Hall, P.M. (1997). Gender, equity and schooling: Policy and practice. NY: Garland Publishing.

Belenky, M.F., Clinchy B.M., Goldberge, N.R., \& Tarule, J.M. (1986). Women's ways of knowing: The development of self, voice, and mind. NY: Basic Books.

Bensimon, E.M., \& Marshall, C. (1997). Policy analysis for post-secondary education: Feminist and critical perspectives. In C. Marshall (Ed.) Feminist critical policy analysis: A perspective for post-secondary education. London: The Falmer Press.

Bogdan, R.C., \& Biklen, S.K. (1992). Qualitative research for education: An introduction to theory and methods. Second Edition. Boston, MA: Allyn and Bacon.

Calas, M.B., \& Smircich, L. (1993). Re-writing gender into organizational theorizing. In J.S. Glazer, E.M. Bensimon, \& B.K. Townsend (Eds.), Women in higher education: A feminist perspective. Needham Heights, MA: Ginn Press.

Caplan, P. J. (1993). Lifting a ton of feathers: A woman's guide for surviving in the academic world. A project of the Council of Ontario Universities Committee on the Status of Women. Toronto, ON: University of Toronto Press. 
Cassuto, L. (1998). Pressures to publish fuel the professionalization of today's graduate students. Chronicle of Higher Education, issue dated Nov. 27.

Chilly Collective ed. (1995). Breaking anonymity: The chilly climate for women faculty. Waterloo, ON: Wilfred Laurier Press.

Chused, R.H. (1985). Faculty parenthood: Law school treatment of pregnancy and child care. Journal of Legal Education, 35, 568-596.

Coiner, C. (1998). Silent parenting in the academy. In C. Coiner \& D.H. George (Eds), The family track: Keeping your faculties while you mentor, nurture, teach, and serve. Chicago: University of Illinois Press.

Committee on the Status of Women. (1988). Employment equity for women: A university handbook. Toronto, ON: Council of Ontario Universities.

Creswell, J.W. (1998). Qualitative inquiry and research design: Choosing among five traditions. Thousand Oaks, CA: SAGE Publications.

Dagg, A.I., \& Thompson, P.J. (1988). Miseducation: Women and Canadian universities. Toronto, ON: OISE Press.

DeBeauvoir, S. (1952 and reprinted 1989). The second sex. NY: Vintage Books.

Donaldson, E.L., \& Emes, C. (2000). The challenge for women academics: Reaching a critical mass in research, teaching, and service. The Canadian Journal of Higher Education, $X X X(3)$, 33-56.

Drakich, J., \& Stewart, P. (1998). A profile of women faculty in Canada: Rank, discipline, and age 1957-1994. In Status of Women (Ed.), Committee Status of women supplement, CAUT Bulletin Insert, 45(4), 7-11.

Duxbury, L., Heslop, L., \& Marshall, J. (1993). Results from faculty questionnaire on work and family roles. Unpublished paper. Carleton University, Ottawa: 1-29.

Finkel, S.K., \& Olswang, S.G. (1996). Child rearing as a career impediment to women assistant professors. The Review of Higher Education, 19(2), 123-139.

Gilligan, C. (1982). In a different voice: Psychological theory and women's development. Cambridge, Mass: Harvard University Press.

Grant, L., Kennelly, I., \& Ward, K.B. (2000). Revisiting the gender, marriage, and parenthood puzzle in scientific careers. Women's Studies Quarterly, 1\&2, $62-85$.

Heald, S. (2002). Reinventing the wheel: Or: Just wondering why we're saying all this again. In S. Heald, (Ed), Women's Issues Network, Ivory towers: Feminist audits. Selected papers from the Win Symposia, 2000-2001. Ottawa: Humanities and Social Sciences Federation of Canada. Retrieved 12/19/03 from: http://www.fedcan/ca/english/policyandadvocacy/win/ivorytwrintro.cfm 
Hensel, N. (1991). Realizing gender equality in higher education: The need to integrate work/family issues. ASHE-ERIC Higher Education Report, n2.Washington, DC: George Washington School of Education and Human Development.

Hochschild, A. (1971). Inside the clockwork of male careers. In F. Howe (Ed) Women and the power to change. NY: McGraw-Hill.

Hornosty, J.M. (1998). Balancing child care and work: The need for a "woman-friendly" university. In J. Stalker \& S. Prentice (Eds), The illusions of inclusion: Women in post-secondary education. Halifax: Fernwood Publishing.

Johnsrud, L.K., \& Heck, R.H. (1994). Administrative promotion within a university: The cumulative impact of gender. Journal of Higher Education, 65 , 25-44.

Kanter, R.M. (1977). Men and women of the corporation. NY: Basic Books.

Keahey, D., \& Schnitzer, D. (2003). The madwoman in the academy: 43 women boldly take on the ivory tower. Calgary: University of Calgary Press.

Lincoln, Y.S., \& Denzin, N.K. (1994). The fifth moment. In N.K. Denzin, \& Y.S. Lincoln (Eds.), Handbook of qualitative research. Thousand Oaks, CA: SAGE Publications.

Long, J.S., Allison, P.D., \& McGinnis, R. (1993). Rank advancement in academic careers: Sex differences and the effects of productivity. American Sociological Review, 58(5), 703-22.

Martin, J.R. (2000). Coming of age in academe: Rekindling women's hopes and reforming the academy. New York: Routledge.

Mather, J. (1998). Fostering women's full membership in the academy. In Status of Women Committee ed. Status of Women Supplement. CAUT Bulletin Insert, 45(4), 2.

McElrath, K. (1992). Gender, career disruption and academic rewards. Journal of Higher Education, 63(3), 269-281.

Noddings, N. (1992). The challenge to care in schools: An alternative approach to education. NY: Teachers College Press.

Orel, A., \& Whitmore R. (1998). Academic careers and babies: Having an academic career and a baby at UCD, personal account of UCD women faculty. Women's Resources and Research Center, University of California, Davis. http://wrrc.ucdavis.edu/babybook/default.html

Park, S.M. (1996). Research, teaching and service: Why shouldn't women's work count? Journal of Higher Education, 67, 47-84.

Reimer, M., Cassin, M., Eyre, L., Gordon, J. (2002). The new rule/s, the university and the consequences for women. In S. Heald, (Ed), Women's Issues Network, Ivory towers: Feminist audits. Selected papers from the Win Symposia, 
2000-2001. Ottawa: Humanities and Social Sciences Federation of Canada. Retrieved 12/19/03 from http://www.fedcan/ca/english/policyandadvocacy/win/ ivorytwrreimer.cfm

Royal Commission on the Status of Women. (1970). Report of the Royal Commission on the Status of Women in Canada. Ottawa: Queen's Printer.

Saunders, M., Therrien M., \& Williams, L. (1998). Creating the "womanfriendly" university: A summary of the CFUW report. In J. Stalker \& S. Prentice (Eds), The illusions of inclusion: Women in post-secondary education. Halifax: Fernwood Publishing.

Smart, M.S., \& Smart, R.C. (1990). Paired prospects: Dual-career couples on campus. Academe, Jan.-Feb., 33-37.

Stanley, J., Robbins W., \& Morgan R. (2002). Selected indicators of the status of women in universities in Canada, 2002. In Women's Issues Network, Ivory towers: Feminist audits. Retrieved 12/19/03 from http://www.fedcan/ca/ english/policyandadvocacy/win/indicators-women.cfm

Stanley, J., Robbins W., \& Morgan R. (2003). Selected indicators of the status of women in universities in Canada, 2002. In Women's Issues Network, Ivory towers: Feminist audits. Retrieved 12/19/03 from http://www.fedcan/ca/ english/policyandadvocacy/win/publications.cfm

Tierney, W.G., \& Bensimon, E.M. (1996). Promotion and tenure: Community and socialization in academe. Albany, NY: State University of New York Press. 